\title{
О.И. Пасиика
}

\section{МЕЖДУНАРОДНАЯ ЯРМАРКА «ВОСТОЧНЫЕ ТОРГИ» ВО ЛЬВОВЕ (20-30-е гГ. ХХ в.) : МИРОВОЙ ОПЫТ И МЕСТНЫЕ РЕАЛИИ}

\begin{abstract}
Рассматривается международная ярмарка «Восточные торги» во Львове как отдельное социально-экономическое явление в контексте выставочно-ярмарочной деятельности и мирового экономического развития. Охарактеризованы «Восточные торги» как выставка экспонатов и политическая демонстрация. Акцентировано внимание на отношении местного населения Львова, мирового сообщества к организации и проведению международной ярмарки как ежегодной государственной манифестации.

Ключевые слова: «Восточные торги»; выставочное мероприятие; Львов; международная ярмарка; внешняя торговля.
\end{abstract}

В 20-х гг. ХХ в. в мировом экономическом пространстве прослеживалось развитие экономики и фабрично-заводской промышленности, торговли, расширялась сеть финансовых институций. Происходила концентрация производства путем создания монопольных объединений, усиливалась конкуренция товаропроизводителей на локальном и международном уровнях. В разных отраслях экономики важным средством укрепления позиции на рынке была выставочно-ярмарочная деятельность. Самыми популярными выставочными мероприятиями были ярмарки (торги). Они выполняли три важные функции: вопервых, удовлетворяли потребности предприятий в представлении продукции; во-вторых, способствовали укреплению позиций в условиях рыночной конкуренции; в-третьих, были способом ознакомления широких слоев населения с новыми товарами и услугами. Но основная цель международных ярмарок - сбыт продукции на местном и заграничных рынках путем заключения договоров.

В первой трети XX в. ярмарки организовывали во многих странах мира. В апреле 1929 г., например, состоялись международные торги во Франкфурте-наМайне, где были представлены товары из Австрии, Италии, Бельгии, Нидерландов, Венгрии, Югославии и других стран [1. С. 9]. В мае 1929 г. состоялась международная ярмарка в Будапеште - важном экономическом, политическом и культурном центре Венгрии. Участниками будапештской ярмарки были предприниматели из Восточной и Западной Европы. В 1930 г. состоялся ряд выставочных мероприятий, в частности в Барселоне (Испания) - международная промышленная выставка; в Стокгольме (Швеция) ремесленная выставка; в Брно (Чехия) - выставка торговли и промысла; Эссене (Германия) - сельскохозяйственная выставка; в Лейпциге (Германия) - международная выставка меха, в которой участвовали США, Великобритания, Франция, Швеция, Норвегия, Голландия, Италия, Венгрия, Австрия, Дания [2. С. 13]. В октябре 1930 г. в Райхенберге (Германия) состоялась юбилейная выставка и торги, посвященные 10летнему юбилею торгов в Райхенберге [3. С. 13]. Обычно международные ярмарки сопровождались разнообразными развлекательными мероприятиями, театральными представлениями, музыкальными, спортивными, торговыми и промышленными конгрессами и служили толчком к развитию туризма.
В первые послевоенные годы Польша, в состав которой входила часть этнических украинских земель, взяла курс на восстановление экономики. В 1921 г. во Львове, который оставался хозяйственной столицей галицких земель, впервые проведена общепольская выставка-ярмарка «Восточные торги». Львов избрали не случайно, поскольку Галичина граничила с Чехословакией, Румынией, УССР. Международные ярмарки во Львове проходили ежегодно и были вторыми по масштабам после «Западных торгов» в Познани (Польша). «Восточные торги» организовывали на государственном уровне с целью налаживания торговых связей со странами Центральной и Восточной Европы. Как правило, в их открытии участвовали польские министры, представители экономических учреждений, а также заграничные дегегати из США, Великобритании, Бельгии, Дании, Эстонии, Франции, Югославии, Германии, Румынии, Венгрии.

Наиболее заинтересованными в проведении «Восточных торгов» во Львове были предприниматели и руководство Польского государства, которое планировало экономическое развитие. Для польских чиновников международные ярмарки «Восточные торги» были одним из важных факторов хозяйственной политики Польши, которая должна была исполнять роль торгового посредника между Западной и Восточной Европой, пропагандировать польскую экономику (промышленность, сельское хозяйство), сформировать единую хозяйственную систему [4. S. 5].

Во львовских «Восточных торгах» принимали участие большинство европейских государств, что содействовало развитию внешней экономики. В ярмарке участвовали 1852 фирмы, из них 244 - заграничные $(13,2 \%)$ [Ibid. S. 38]. Доминировали австрийские и французские фирмы. В 1925 г. в международной ярмарке во Львове участвовало свыше 1500 предприятий, среди них 350 - зарубежые. Ярмарку посетило около 120 тыс. человек. На первых торгах выделялись товары металлургической промышленности, в том числе сельскохозяйственная техника. Широко была представлена легкая, пищевая, деревообрабатывающая, электротехническая, химическая промышленность. В 1929-1933 гг. в связи с экономическим кризисом количество заграничных предприятий уменьшилась. В юбилейной 10-й ярмарке свои стенды подготовили 1483 фирмы, из них свыше 300 (20,29\%) из-за рубежа, которые представляли 19 стран. В час- 
ности 1016 фирм представляли промышленность и торговлю.

Впервые участвовали в выставке фирмы из Чили и Португалии. Больше всего фирм было из Венгрии, Австрии, Германии, Румынии [5. S. 2-4]. В 1933 г. лишь 650 фирм участвовали в ярмарке, из них 113 заграничных, а количество посетителей уменьшилась до 90 тыс. В послекризисный период прослеживалось оживление на международных торгах во Львове. В XVII «Восточных торгах» 1937 г. участвовало 1158 фирм, в частности 254 заграничных [6. С. 50].

Большой популярностью на львовских торгах пользовались импортные товары, а именно: автомобили из Австрии, Франции, Германии; телефоны, галантерейные изделия, медицинская техника, оптические приборы из Австрии и Германии; ликеры и вина из Франции, Венгрии; часы из Чехословакии. С каждым годом количество румынских и венгерских товаров увеличивалось. В основном это была сельскохозяйственная продукция, табак, вино. Из Турции, Египта привозили ковры; из Португалии рыбные консервы; из Бельгии, Швейцарии, Швеции, США - бытовую технику и другие товары. На $\mathrm{X}$ «Восточных торгах» лучше всего была представлена пищевая (206 фирмы), легкая (128 фирмы) и металлургическая промышленность (125 фирмы). Купцы из УССР заказывали ткани, сельскохозяйственную технику, канцелярские приборы. Западноевропейские покупатели скупали ковры, мех, дерево (сырье), стекло, электротехнические изделия [5. S. 14].

Общественность по-разному оценивала организацию, проведение, перспективы и результаты международных ярмарок во Львове. Польская и мировая пресса в основном положительно отзывалась о проведении выставочного мероприятия : «,„Восточные торги" во Львове могут иметь такое же значение, как имели ярмарки в Нижнем Новгороде. Географическое положение Львова и его традиции как выдающегося центра на старом торговом пути дает большую пользу» («Suisse». Женева 1922 г.) [4. S. 58]. Корреспондент популярного французского издания писал о вторых львовских торгах: «Их успех значителен, в сравнении с предыдущим годом» («L'information Financière», Париж, 1922) [Ibid. S. 50]. Генеральный консул Австрии Евгениуш Вурциян отмечал, что австрийское купечество надеется на «Восточных торгах» наладить отношения не только с польскими, но также с русскими, украинскими и румынскими покупателями, а значение Торгов заключается в том, что они являются связующим звеном торговли центральноевропейской с Востоком [Ibid. S. 65]. Зато местная украинская пресса критически отзывалась о международной ярмарке, отмечая, что с каждым годом уменьшалось количество участников и росли налоги [7-9; 10. C. 52].
«Восточные торги» во Львове имели и определенные негативные моменты. Местное население жаловалось на падение стоимости польской марки (впоследствии - злотого) и повышение цен на товары первой необходимости, на ярмарке было много иностранных товаров (25\%). Для примера, на чешских международных торгах заграничных товаров было не больше 4\%, что влияло на увеличение спроса на чешский товар и повышение стоимости кроны [11. С. 5].

Кроме экономических, были и общественнополитические причины, предопределенные локальными историческими особенностями. Галицкие украинцы-предприниматели и купцы почти не были задействованы в «Восточных торгах». Украинцы Галичины считали международную ярмарку политической акцией, которую организовывали во Львове с целью показать, что Восточная Галичина и Львов являются частью Польши [12. С. 7]. Подтверждение этому многочисленные заявления руководящих органов Польши и само оформление выставочных мероприятий. В частности, на первом павильоне «Восточных торгов» была надпись: «Laborem nostrum patriae» (Наш труд Отчеству) [13. S. 14]. В печатных польских изданиях Торгово-промышленной палаты часто публиковали статьи под заглавием «Нет Польши и Львова без Восточных Торгов». Известный польский общественно-политический деятель и критик Адольф Новачинский в издании, посвященном V «Восточным торгам», трактовал международную ярмарку во Львове так: «Еще раз должны осознать, что львовские торги - это не только коммерция, это не только выставка экспонатов, это не только экзамен зрелости по „польской экономике”, это не только павильоны и базар! Это не только наследство традиционных давних славных „киевских контактов”, потому это не только такие торги, как в Леоне, Стокгольме, Праге, Липске, Крулевце (Кенигсберге), нет, это не только ярмарка с развлекательными мероприятиями и коммерция, но это также „политика”, важное и серьезное заявление: «здесь стоим и здесь стоять будем", „поэтому я работаю”, „создаю и произвожу, поэтому заслуживаю на уважение, на веру, на кредит"» [13. S. 22]. Вице-министр Министерства иностранных дел Генрик Страсбургер также неоднократно делал акцент на том, что львовские торги имели не только хозяйственное, но и политическое значение [4. S. 6]. Таким способом поляки манифестировали перед украинцами и иностранцами тесную связь Львова с Польшей.

Международную ярмарку «Восточные торги» организовывали во Львове до 1939 г. Благодаря львовским торгам оживились внешнеэкономические связи Польши со странами Центральной и Восточной Европы, особенно с Болгарией, Румынией, Венгрией. Однако общественно-политические события препятствовали активизации роли Львова в мировой торговле.

\section{ЛИТЕРАТУРА}

1. Франкфуртські торги 14-17 квітня 1929 р. // Український купець. 1929. Квітень. С. 9.

2. Виставки // Український купець. 1929. Травень. С. 13.

3. Ювілейна виставка в Райхенбергу // Український купець. 1929. Травень. С. 13.

4. Targi Wschodnie: rozwoj i perspectywy. Lwow : Nakladem Targów Wschodnich, 1921. $67 \mathrm{~s}$

5. X jubileuszowe Targi Wschodnie: structura i przebieg. Lwow : Nakladem Targów Wschodnich, 1923. 27 s. 
6. Історія Львова. У трьох томах / редкол.: Я. Ісаєвич, М. Литвин, Ф. Стеблій. Львів : Центр Європи, 2007. Т. 3. 575 с.

7. X. jubileuszowe międzynarodowe Targi Wschodnie we Lwowie: oficialny przewodnik i spis wystawców. Lwów, 1930.68 s.

8. Przewodnik po drugich «Targach Wschodnich» we Lwowie od 5. XI do 15. XI. 1922: Spis wystawców. Warszawa, 1922. 70 s.

9. Безсмертний А. «Східні торги» у Польщі 1920-ті-1930-ті рр. ХХ ст. // Історична панорама. 2014. Вип. 19. С. 55-68.

10. Ілюстрований господарський календар на 1930 р. Львів, 1929. С. 52.

11. Правда про «Таргі всходнє» // Слово. 1922. 1 жовтня. С. 5.

12. Д. П. Східні торги у Львові // Новий час. 1926. 7 вересня. С. 7.

13. Targi Wschodnie we Lwowie w świetle polityki gospodarczej Polski. Lwów : Slowo Polskie, 1925. 48 s.

Статья представлена научной редакцией «История» 12 марта 2017 г.

\section{INTERNATIONAL FAIR 'EASTERN TRADES' IN LVIV (1920S-1930S): WORLD EXPERIENCE AND LOCAL REALITIES}

Vestnik Tomskogo gosudarstvennogo universiteta - Tomsk State University Journal, 2018, 430, 107-109.

DOI: $10.17223 / 15617793 / 430 / 14$

Oksana I. Pasitska, Institute of Ukrainian Studies named after I. Krypyakevych of National Academy of Sciences of Ukraine (Lviv, Ukraine). E-mail: pasitska@ukr.net

Keywords: 'Eastern Trades'; exhibition; Lviv; international fair; foreign trade.

For many world-leading countries, international fairs were important forms of economic policy in the 1920s-1930s. They were organised to improve foreign trade relations. Selected organisational aspects of the 'Eastern Trades' in Lviv are covered in various publications regarding the history of Lviv, most notably in the research carried out by the historian A. Bezsmertnyi. However, Lviv trades were not studied as a separate social and economic phenomenon, from the point of view of the world experience and local peculiarities, which forms the main sphere of the research of this article. The aim of this research is to present the international fair 'Eastern Trades' in Lviv in the 1920s-1930s as a socio-economic phenomenon in the context of the world economic development, of exhibitions and fairs held in Poland. The following controversial issues are discussed: what the purpose of organising international fairs in Lviv was, who was particularly interested in holding such events, which countries participated in them, how the local citizens and the world community reacted to the organisation and conduct of Lviv trades, why they did not have a dramatic influence on the role of Lviv in the world market. Materials used for writing the article are collected from the Galician press of the interwar period of the twentieth century, which presents the main aspects of the organisation, conduct and results of 'Eastern Trades' as well as the attitude of the local people to the given event. In addition, a number of specialised publications of the Chamber of Commerce and Industry in Lviv were used, where statistical materials were published, as well as the memoirs of the bidders. International fairs 'Eastern Trades' in Lviv, which were held at the country level between 1921 and 1939, were the second largest trading events, with the first place occupied by Poznań trades in Poland. Lviv trades were reminiscent of the world exhibitions, but they had their local peculiarities. These were not only economic exhibitions, but also political demonstrations. Exhibitions and fairs were attended by representatives of foreign firms from more than 20 countries, among them Hungary, Romania, Austria, Germany and France. 'Eastern Trades' revived Polish foreign trade relations with the countries of Central and Eastern Europe. However, due to the difficult social and political situation, they could not dramatically increase the participation of the local Ukrainian entrepreneurs and strengthen the role of Lviv in the international trade.

\section{REFERENCES}

1. Ukraïns'kiy kupets'. (1929) Frankfurts'ki torgi 14-17 kvitnya 1929 r. [Frankfurt trades, April 14-17, 1929]. Ukrä̈ns'kiy kupets'. April. pp. 9.

2. Ukraïns'kiy kupets'. (1929) Vistavki [Exhibitions]. Ukrä̈ns 'kiy kupets'. May. pp. 13.

3. Ukraïns'kiy kupets'. (1929) Yuvileyna vistavka v Raykhenberru [Jubilee exhibition in Reichenburg]. Ukrä̈ns 'kiy kupets'. May. pp. 13.

4. Anon. (1921) Targi Wschodnie: rozwoj i perspectywy [Eastern Trades: development and perspectives]. Lviv: Nakladem Targów Wschodnich.

5. Anon. (1923) Kh jubileuszowe Targi Wschodnie: structura i przebieg [X Jubilee of Eastern Trades: structure and mileage]. Lviv: Nakladem Targów Wschodnich.

6. Isaevich, Ya, Litvin, M. \& Stebliy, F. (eds) (2007) Istoriya L'vova. U tr'okh tomakh [History of Lviv. In three volumes]. Vol. 3. L'viv: Tsentr Evropi.

7. Anon. (1930) Kh. jubileuszowe międzynarodowe Targi Wschodnie we Lwowie: oficialny przewodnik i spis wystawców [X Jubilee of the international Eastern Trades in Lviv: an official guide and list of exhibitors]. Lviv: [s.n.].

8. Anon. (1922) Przewodnik po drugich "Targach Wschodnich" we Lwowie od 5. XI do 15. XI. 1922: Spis wystawców [Guide to the second "Eastern Trades" in Lviv from 5th to 15th March, 1922: List of exhibitors]. Warsaw: [s.n.].

9. Bezsmertniy, A. (2014) "Skhidni torgi" u Pol'shchi 1920-ti-1930-ti rr. XX st. ["Eastern Procurement" in Poland in the 1920s-1930s]. Istorichna panorama. 19 . pp. 55-68.

10. Anon. (1929) Ilyustrovaniy gospodars 'kiy kalendar na 1930 r. [Illustrated economic calendar for 1930]. Lviv: [s.n.]. pp. 52.

11. Slovo. (1922) Pravda pro "Tarri vskhodne" [The truth about "Eastern Trades"]. Slovo. 1 October. pp. 5.

12. D.P. (1926) Skhidni torgi u L'vovi [Eastern Trades in Lviv]. Noviy chas. 7 September. pp. 7.

13. Anon. (1925) Targi Wschodnie we Lwowie w'sietle polityki gospodarczej Polski [The 13th Eastern Trades in Lviv in the light of Poland's economic policy]. Lviv: Slowo Polskie. 